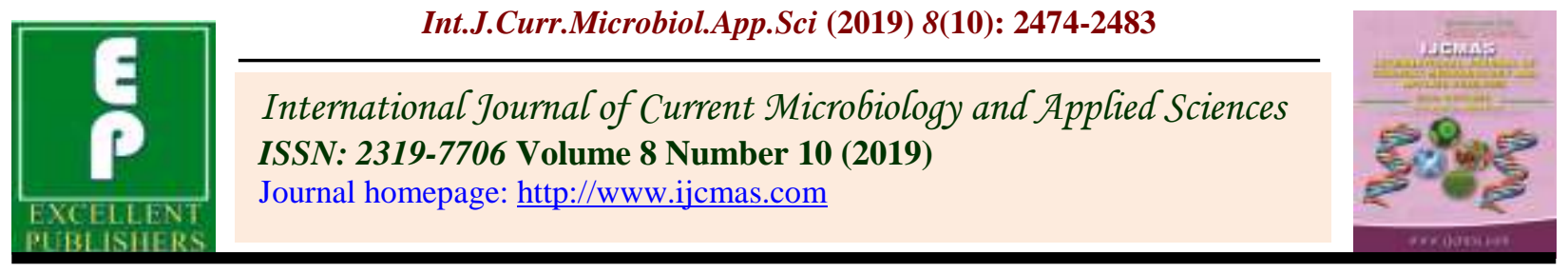

Original Research Article https://doi.org/10.20546/ijcmas.2019.810.287

\title{
Assessment of Genetic Diversity in Elite Genotypes of Okra [Abelmoschus esculentus (L.) Moench]
}

\author{
Dhaval Rathava, A. I. Patel*, J. M. Vashi and B. N. Chaudhari \\ Department of Genetics and Plant Breeding, N. M. College of Agriculture, \\ Navsari Agricultural University, Navsari (Gujarat), India \\ *Corresponding author
}

\begin{tabular}{|c|}
\hline Keywords \\
\hline $\begin{array}{l}\text { Genetic variation, } \\
\text { Genotype, } \\
\text { Phenotype, } \\
\text { Heritability, } \\
\text { Genetic advance }\end{array}$ \\
\hline Article Info \\
\hline $\begin{array}{l}\text { Accepted: } \\
\text { 17 September } 2019 \\
\text { Available Online: } \\
10 \text { October } 2019\end{array}$ \\
\hline
\end{tabular}

\section{A B S T R A C T}

An attempt was made to assess the genetic variability, heritability and genetic advance in okra [Abelmoschus esculentus (L.) Moench] using 31 diverse genotypes; were grown in randomized block design with three replications during kharif 2018 at college farm, N. M. College of Agriculture, Navsari Agricultural University, Navsari, Gujarat (India). Observations were recorded on ten characters showing considerable variability. Mean values were used to determine characters' phenotypic and genotypic variances, phenotypic and genotypic coefficients of variation, broad sense heritability and genetic advance as percentage of mean. Significant variation existed in all the characters. The phenotypic coefficient of variations was found slightly higher than the genotypic coefficient of variations for all characters studied, indicating that the apparent variation is not only genetic but also influenced by the growing environment in the expression of the traits. The moderate magnitude of PCV and GCV was observed for internodal length and number of fruits per plant. High heritability coupled with high genetic advance as per cent of mean was observed for internodal length and number of fruits per plant revealing the importance of additive gene action in the inheritance of these characters and suggested reliable okra improvement through selection of the traits.

\section{Introduction}

Okra [Abelmoschus esculentus (L.) Moench] is commonly known as Lady's Finger in England, Gumbo in the USA and Bhindi in India. It is ancient and economically important vegetable crop cultivated throughout the world and is a native of tropical Africa. Okra is an annual vegetable crop propagated by seeds in tropical and subtropical region of the world like India, Africa, Turkey and other neighbouring countries. Its tender fruits are used as a vegetable and are generally marketed in fresh state, but sometimes in canned or dehydrated form. In India, okra is one of the most important vegetable crops grown for its tender green fruits during summer and rainy seasons. It is a member of 
Mallow or Malvaceae family with $2 \mathrm{n}=8 \mathrm{x}=72$ to 144 chromosomes and is polyploid in nature. There are 30 species under genus Abelmoschus in the old world and four in the new world (Joshi and Hardas, 1956). Out of them, Abelmoschus esculentus $(2 \mathrm{n}=130)$ is the only species known to be cultivated extensively. Okra is a self-pollinated crop, however occurrence of out crossing to an extent of 4 to 19 per cent (Choudhury and Choonsai, 1970) by insects has been reported which renders considerable genetic diversity.

Creation and utilization of variability using proper breeding procedure is a pre-requisite for the genetic improvement of any crop. Generally, amount of variability is more in the early segregating generations as compared to later generations. The phenotypic expression of the plant character is mainly controlled by the genetic makeup of the plant and the environment in which it is growing. Therefore, it becomes necessary to partition the observed phenotypic variability into its heritable components with suitable parameters such as phenotypic and genotypic coefficient of variation, heritability and genetic advance as per cent of mean.

Genetic improvement of a crop is pivoted on the strength of genetic diversity within the crop species. Adequate variability provides options from which selections are made for improvement and possible hybridization. Heritability assumes that individuals more closely related are more likely to resemble one another than distant ones (Falconer). Estimate of heritability assists breeders to allocate resources necessary to effectively select for desired traits and to achieve maximum genetic gain with little time and resources. There are different ways to calculate heritability. It may be estimated as broad-sense or narrow-sense, on single plant, individual plot or mean of entry. Genetic advance explains the degree of gain obtained in a character under a particular selection pressure. High genetic advance coupled with high heritability estimates offers the most suitable condition for selection. It also indicates the presence of additive genes in the trait and further suggest reliable crop improvement through selection of such traits. Estimates of heritability with genetic advance are more reliable and meaningful than individual consideration of the parameters.

Continuous improvement of okra is imperative which can be achieved through effective selection of suitable parent materials of significant genetic variability. The objective of the present study was to estimate the genetic variation, heritability and expected genetic advance in the elite okra genotypes and to evaluate suitable selection criteria for further breeding.

\section{Materials and Methods}

Diverse genotypes of okra totalling 31(Table 1), were obtained from different research stations for the study were grown in randomized block design with three replications. Each entry was presented by a single-row plot of ten plants, spaced at $60 \times 30$ $\mathrm{cm}$. The present experiment was carried out in kharif 2018 at college farm, N. M. College of Agriculture, Navsari Agricultural University, Navsari, Gujarat. All recommended horticultural package of practices were applied for field maintenance and harvesting.

Data was recorded on ten parameters viz., days to $50 \%$ flowering, internodal length, number of branches per plant, plant height, number of fruits per plant, fruit length, fruit diameter, fruit weight, fruit yield per plant and fiber content. The GCV and PCV were determined according to Cockerham (1963). Heritability in broad sense was calculated using formula proposed by Allard (1960) and expressed in percentage. Genetic advance for each character was predicted by the formula given 
by Johnson et al., (1955). Mean values were used to determine characters' variances, coefficients of variation, broad sense heritability and genetic advance percentage of mean.

\section{Results and Discussion}

The genotypic variance followed the trend of phenotypic variance and was greater than environmental variance for all the characters. This implied that phenotypic variability might be considered as a reliable measure of genotypic variability. In the present study, the phenotypic and genotypic variances were greater than the environmental variance for all the character under study except number of branches per plant and fruit yield per plant where genotypic variance is lower than environmental variances. Similar results were obtained by Kumar et al., (2019) for number of branches per plant and by Bello et al., (2015) for fruit yield per plant, which indicated that influence of environment on expression of traits was lower or negligible, hence selection would be effective (Table 2).

With view to compare different quantitative characters in respect of phenotypic and genotypic variability, phenotypic coefficient of variation and genotypic coefficient of variation were calculated. The genotypic coefficient of variation measures the range of inherent variation present in a character and helps to compare the variability present in different characters. The PCV and GCV measure the extent of variation present in the population in the particular character. In the present investigation, PCV was higher than the respective GCV for all the traits studied, revealing that the environment had an important role to play in influencing the expression of these characters which is in accordance with findings of Sundaram and Rajkumar (2015), Khajuria et al., (2015), Kandasamy et al., (2015), Jadhav et al.,
(2016), patil et al., (2017), Singh et al., (2017), Niraja et al., (2018) and Priyanka et al., (2018).

The moderate magnitude of GCV and PCV was observed for internodal length and number of fruits per plant. This is in relation with the earlier reports of Akotkar et al., (2010), Ramanjinappa et al., (2011), Chandra et al., (2014), Mallesh et al., (2015), Chandramouli et al., (2016), Mohammad and marker (2017a) and Ullangula (2017) for internodal length and with Adiger et al., (2011), Prakash et al., (2011a), Ramanjinappa et al., (2011), Pooja et al., (2011), Chandra et al., (2014), Kumar and Kumar et al., (2014), Sundaram and Rajkumar (2015), Chandramouli et al., (2016), Shivaramegowda et al., (2016), Yadav et al., (2016), Meenakshi et al., (2017) and Singh et al., (2017) for number of fruits per plant.

However, low magnitudes of GCV and PCV were recorded for days to $50 \%$ flowering, average fruit length, average fruit diameter, average fruit weight and fiber content, among which the average fruit weight has the lowest GCV and PCV. The most probable reason could be the phenotypic plasticity occurring in these traits is the main source of variation than the genetic variance. Such result also indicated that selection is not effective for these traits because of the narrow genetic base (Vishwas 2019). Lower magnitude of GCV and PCV were also reported by Pooja et al., (2011), Jagan et al., (2013), Archana et al., (2015), Chandramouli et al., (2016), Patil et al., (2017), Niraja et al., (2018), Priyanka et al., (2018) and Kumar et al., (2019) for days to 50 $\%$ flowering; Patel et al., (2014), Jadhav et al., (2016), Sharma et al., (2016), Meenakshi et al., (2017), Priyanka et al., (2018) and Kumar et al., (2019) for average fruit length; Adiger et al., (2011), Chandra et al., (2014), Archana et al., (2015), Khajuria et al., (2015), Sharma and Prasad (2015), Jadhav et al., (2016), 
Shivaramegowda et al., (2016), Mohammad and marker (2017a), Ullangula (2017), Niraja et al., (2018), Vrunda et al., (2018) and Kumar et al., (2019) for average diameter; Ramanjinappa et al., (2011), Rekha et al., (2015), Chandramouli et al., (2016), Sharma et al., (2016), Singh et al., (2017) and Priyanka et al., (2018) for average fruit weight.

The low magnitudes of GCV and moderate magnitudes of PCV respectively, was observed for number of branches per plant, plant height and fruits yield per plant. This is in relation with the earlier reports of Akotkar et al., (2010), Mallesh et al., (2015), Rekha et al., (2015), Sundaram and Rajkumar (2015) and Kumar et al., (2019) for number of branches per plant; Archana et al., (2015), Rekha et al., (2015) and Chandramouli et al., (2016) for plant height and Jagan et al., (2013) and Kumar et al., (2019) for fruits yield per plant.

In the present study, the difference between PCV and GCV were lower for most of the characters except number of branches per plant which suggesting negligible role of environment in the expression of traits, so improvement in these traits is easily possible by phenotypic selection.

Heritability is important genetic parameter, which serves as an index of transmissibility of the character in the next generation. Heritability estimates show the amount of heritable and non heritable components of variation exhibited by the individual trait.

The genetic advance is the improvement in the characters of selected population over the base population. Heritability, however indicates only the effectiveness with which selection of a genotype can be based on phenotypic performance, but fails to indicate the genetic progress. Heritability estimates along with genetic gains are more effective and reliable in predicting the improvement through selection (Johnson et al., 1955).

In the present study, high heritability coupled with high genetic advance as per cent of mean was observed for internodal length and number of fruits per plant revealing the importance of additive gene action in the inheritance of these characters. Similar results were reported for internodal length by Phanikrishna et al., (2015), Sundaram and Rajkumar (2015), Chandramouli et al., (2016), Mohammad and marker (2017a), Patil et al., (2017), Singh et al., (2017) and Ullangula (2017) and for number of fruits per plant by Shivaramegowda et al., (2016), Badiger et al., (2017), Meenakshi et al., (2017), Mohammad and marker (2017a), Patil et al., (2017), Singh et al., (2017), Ullangula (2017) and Vrunda et al., (2018).

In the present study, high heritability coupled with moderate genetic advance was recorded for plant height, average fruit length and fiber content.

The result was in agreement with the finding of Kumar and Kumar (2014), Patel et al., (2014) and Pachiyappan and Saravannan (2016) for plant height and Pachiyappan and Saravannan (2016), Shivaramegowda et al., (2016), Meenakshi et al., (2017), Mohammad and marker (2017a), Patil et al., (2017), Singh et al., (2017) and Priyanka et al., (2018) for average fruit length.

The high heritability coupled with low genetic advance was recorded for days to $50 \%$ flowering and average fruit diameter. It infers that this character was regulated by nonadditive gene action. The heritability is being exhibited due to the low influence of environment over the genotype and simple selection will not be rewarding due to the predominance of non-additive genes. 
Table.1 List of okra genotypes used in experiment

\begin{tabular}{|l|c|c|}
\hline Sr. No. & Genotypes & Sources \\
\hline 1. & Parbhani Kranti & MKV, Parbhani \\
\hline 2. & Arka Abhay & IIHR, Bangalore \\
\hline 3. & Arka Anamika & IIHR, Bangalore \\
\hline 4. & Kashi kranti & IIVR, Varanasi \\
\hline 5. & Pusa Sawani & IARI, New Delhi \\
\hline 6. & VRO-6 & IIVR, Varanasi \\
\hline 7. & HRB-55 & HAU, Hissar \\
\hline 8. & NOL-16-3 & NAU, Navsari \\
\hline 9. & NOL-16-6 & NAU, Navsari \\
\hline 10. & NOL-17-1 & NAU, Navsari \\
\hline 11. & NOL-17-2 & NAU, Navsari \\
\hline 12. & NOL-17-3 & NAU, Navsari \\
\hline 13. & NOL-17-5 & NAU, Navsari \\
\hline 14. & NOL-17-6 & NAU, Navsari \\
\hline 15. & NOL-17-7 & NAU, Navsari \\
\hline 16. & NOL-17-8 & NAU, Navsari \\
\hline 17. & NOL-17-10 & NAU, Navsari \\
\hline 18. & GAO-5 & AAU, Anand \\
\hline 19. & AOL-09-2 & AAU, Anand \\
\hline 20. & AOL-12-52 & AAU, Anand \\
\hline 21. & AOL-13-73 & AAU, Anand \\
\hline 22. & AOL-13-144 & AAU, Anand \\
\hline 23. & AOL-14-32 & AAU, Anand \\
\hline 24. & JOL-08-2 & JAU, Junagadh \\
\hline 25. & JOL-08-4 & JAU, Junagadh \\
\hline 26. & JOL-09-4 & JAU, Junagadh \\
\hline 27. & JOL-09-5 & JAU, Junagadh \\
\hline 28. & JOL-11-12 & JAU, Junagadh \\
\hline 29. & JOL-13-05 & JAU, Junagadh \\
\hline 30. & JOL-14-10 & JAU, Junagadh \\
\hline 31. & JDNOL-11-12 & JAU, Junagadh \\
\hline
\end{tabular}


Table.2 Range, mean, GCV \%, PCV \%, heritability $\left(\mathrm{h}^{2}\right.$ bs $\left.\%\right)$ and genetic advance as per cent of mean (GAM \%) for various traits in okra genotypes

\begin{tabular}{|c|c|c|c|c|c|c|c|c|c|c|}
\hline \multirow{2}{*}{$\begin{array}{l}\text { Sr. } \\
\text { No }\end{array}$} & \multirow[t]{2}{*}{ Character } & \multirow[t]{2}{*}{ Range } & \multirow[t]{2}{*}{ Mean } & \multicolumn{3}{|c|}{ Component of variance } & \multirow{2}{*}{$\begin{array}{c}\text { GCV } \\
\%\end{array}$} & \multirow[t]{2}{*}{ PCV\% } & \multirow[t]{2}{*}{$\mathbf{h}^{2}{ }_{\mathrm{bs}} \%$} & \multirow{2}{*}{$\begin{array}{c}\text { GAM } \\
\%\end{array}$} \\
\hline & & & & $\sigma_{e}^{2}$ & $\sigma_{\mathrm{g}}^{2}$ & $\sigma_{p}^{2}$ & & & & \\
\hline 1 & Days to $50 \%$ flowering & $39.66-50.33$ & 43.96 & 1.79 & 5.49 & 7.28 & 5.33 & 6.14 & 75.40 & 9.53 \\
\hline 2 & Internodal length $(\mathrm{cm})$ & $4.38-8.00$ & 6.11 & 0.18 & 0.71 & 0.89 & 13.78 & 15.43 & 79.80 & 25.37 \\
\hline 3 & Number of branches per plant & $2.00-3.30$ & 2.67 & 0.17 & 0.04 & 0.21 & 7.56 & 17.44 & 18.80 & 6.75 \\
\hline 4 & Plant height $(\mathrm{cm})$ & $97.18-138.94$ & 121.87 & 36.96 & 129.55 & 166.51 & 9.33 & 10.58 & 77.80 & 16.97 \\
\hline 5 & Number of fruits per plant & $9.86-15.06$ & 12.25 & 0.37 & 1.95 & 2.32 & 11.40 & 12.44 & 84.00 & 21.54 \\
\hline 6 & Average fruit length $(\mathrm{cm})$ & $9.54-12.07$ & 11.06 & 0.13 & 0.41 & 0.55 & 5.84 & 6.70 & 76.00 & 10.48 \\
\hline 7 & Average fruit diameter $(\mathrm{cm})$ & $1.36-1.78$ & 1.58 & 0.005 & 0.008 & 0.013 & 5.66 & 7.20 & 61.90 & 9.18 \\
\hline 8 & Average fruit weight (g) & $11.90-14.20$ & 13.47 & 0.28 & 0.23 & 0.51 & 3.56 & 5.34 & 44.40 & 4.88 \\
\hline 9 & Fruit yield per plant (g) & $132.24-210.24$ & 167.32 & 351.53 & 244.19 & 595.73 & 9.33 & 14.58 & 41.00 & 12.31 \\
\hline 10 & Fiber content $(\%)$ & $3.73-5.27$ & 4.71 & 0.05 & 0.10 & 0.16 & 6.99 & 8.58 & 66.40 & 11.73 \\
\hline
\end{tabular}


However, these traits can be improved in heterosis breeding programme by development of hybrid and also by exploitation of transgressive segregants. The result was in agreement with the finding of Chandramouli et al., (2016), Patil et al., (2017) and Priyanka et al., (2018) for days to $50 \%$ flowering and for average fruit diameter by Chandra et al., (2014), Bello et al., (2015), Bello and Aminu (2017) and Patil et al., (2017).

Moderate heritability in conjunction with moderate genetic advance was observed for fruit yield per plant which indicates the role of both additive and non -additive gene action governing the inheritance of this trait and offers the best possibility of improvement through progeny selection or any modified selection procedures aiming to exploit the additive gene effects. Similar results were reported by Archana et al., (2015), Badiger et al., (2017) and Priyanka et al., (2018).

The moderate heritability coupled with low genetic advance was recorded for average fruit weight. Similar results were reported by Priyanka et al., (2018). The low heritability coupled with low genetic advance was recorded for number of branches per plant indicating high influence of environment and consequently its selection may not be effective. The result was in agreement with the finding of Sharma and Prasad (2015), Pachiyappan and Saravannan (2016) and Badiger et al., (2017).

The present results indicated that high heritability coupled with high genetic advance and moderate to high GCV and PCV were recorded for internodal length and number of fruits per plant indicating the role of additive gene action in the inheritance of these traits, hence further improvement in these characters would be achieved by selection in the present material.

\section{References}

Adiger, S., Shanthilkumar, G., Gangashetty, P. I. and Salimath, P. M. (2011). Research Note Association studies in okra [Abelmoschus esculentus (L.) Moench]. Ele. J. PL. Br., 2(4): 568573

Akotkar, P. K., De, D. K. and Pal, A.K. (2010). Genetic variability and diversity in okra [Abelmoschus esculentus (L.) Moench]. Elec. J. Pl. Br., 1 (4): 393-398.

Allard, R. W. (1960). Principles of plant breeding, 04: SB123, A5.

Archana, M., Mishra H. N., Senapati N. and Tripathy P. (2015). Genetic variability and correlation studies in Okra [Abelmoschus esculentus (L.) Monech]. Elec. J. Pl. Br., 6(3): 866869.

Badiger, M., Pitchaimuthu, M. and Pujer, P. (2017). Genetic variability, heritability, genetic advance and correlation studies among quantitative traits in okra [Abelmoschus esculentus (L.) Moench]. Global J. Biosci. \& Biotech., 6(2): 314-319.

Bello, B. O. and Aminu, D. (2017). Genetic relationships among okra [Abelmoschus esculentus (L.) Moench] cultivars in Nigeria. Acta Agri. Slovenica, 109(2): 251-260.

Bello, O. B., Aminu, D., Gambo, A., Azeez, A. H., Lawal, M., Ali, I. and Abdulhamid, U. A. (2015). Genetic diversity, heritability, genetic advance in okra [Abelmoschus esculentus (L.) Moench]. Bangladesh J. Pl. Br. \& Genet., 28(2): 25-38.

Chandra, S., Bhardwaj, M., Kumar, R., Kumar, D., Kumar, S., Gautam, N. and Sharma, S. (2014). Estimation of parameters of variability for different quantitative traits in okra [Abelmoschus esculentus (L.) 
Moench]. Int. J. Farm Sci., 4(3): 3341.

Chandramouli, B., Shrihari, D., Rao, A.V.D. and Rao, M.P. (2016). Studies on genetic variability, heritability and genetic advance in okra [Abelmoschus esculentus (L.) Moench] genotypes. Pl. Archives, 16(2): 679-682.

Choudhury, B and Choonsai, M. L. A. (1970). Natural cross-pollination in some vegetable crops. Indian J. Agric. Sci., 40(9): 805-812.

Cockerham, C. C. (1963). Estimation of genetic variance in statistical Genetics and Plant breeding. National research council, Washington, DC, pp:53.

Falconer, D. S. and Mackay, F.C. Introduction to quantitative genetics, fourth ed. Longman, New York, 1996464.

Jadhav, R. A., Bagwale, S. B., Jawale, L. N. and Deosarkar, D. B. (2016). Genetic variability studies for yield, yield contributing and quality traits in okra [Abelmoschus esculentus (L.) Moench]. Indian J. Agric. Res., 50(6): 614-618.

Jagan, K., Reddy, R. K., Sujatha, M., Sravanthi, V. and Reddy, M. S. (2013). Studies on genetic variability, heritability and genetic advance in okra [Abelmoschus esculentus (L.) Moench]. IOSR J. Agric. Vet. Sci., 5(1): 59-61.

Johnson, H. W., Robinson, H. R. and Comstock, R. E. (1955). Estimation of genetic and environmental variability in soybean (Glycine max L.). Agron. J., 47: 314-318.

Joshi, A. B. and Hardas, M. W. (1956). Alloploid nature of okra, [Abelmoschus esculentus (L.) Moench]. Nature, 178: 1190-1191.

Kandasamy, R. (2015a). Variability studies in okra [Abelmoschus esculentus (L.) Moench]. The Asian J. Horti., 10(1): 60-63.
Khajuria, R. K., Sharma, J. P., Samnotra, R. K., Kumar, S. and Ranjit, K. (2015). Variability studies in okra (Abelmoschus esculentus L.). Elec. J. Pl. Br., pp: 226-234.

Kumar, A., Kumar, M., Sharma, V. R., Singh, M. K., Singh, B. and Chand, P. (2019). Genetic variability, heritability and genetic advance studies in genotypes of okra [Abelmoschus esculentus (L.) Moench]. J. Pharm. \& Phyto., 8(1): 1285-1290.

Kumar, A., Kumar, M., Sharma, V. R., Singh, M. K., Singh, B. and Chand, P. (2019). Genetic variability, heritability and genetic advance studies in genotypes of okra [Abelmoschus esculentus (L.) Moench]. J. Pharm. \& Phyto., 8(1): 1285-1290.

Kumar, P. and Kumar, R. (2014). Variability, heritability and character association in okra [Abelmoschus esculentus (L.) Moench]. Asian J. Bio Sci., 9(1): 9-13.

Mallesh, S., Revanappa, S. S., Prabhakar, B. and Mangi, V. (2015). Genetic variability studies in okra [Abelmoschus esculentus (L.) Moench]. J. Life Sci., 10(4): 20812084.

Meenakshi, K., Solankey, S. S., Shirin, A. and Neha, P. (2017). Assessment of genetic variability and character association in okra genotypes for yield and contributing characters. J. App. \& Natural Sci., 9(3): 1825-1830.

Mohammad, S. and Marker, S. (2017a). Variability studies for various quantitative traits for selection of elite genotypes in okra [Abelmoschus esculentus (L.) Moench]. Int. J. Pure App. Biosci., 5(4): 1785-1790.

Niraja, R. P., Nayak, N. J. and Baisakh, B. (2018). Evaluation of elite genotypes for YVMV resistance in okra [Abelmoschus esculentus (L.) Moench]. Int. J. Curr. Microbiol. App. 
Sci., 7(12): 594-608.

Pachiyappan, R. and Saravannan, K. (2016). Studies on genetic variability and correlation for fruit yield and fruit quality characters of okra. Asian $J$. Horti., 11(1): 101-104.

Patel, R., Sengupta, S. K. and Verma, A. K. (2014). Studies on genetic parameters in okra [Abelmoschus esculentus (L.) Moench]. Trends in Biosci., 7(14): 1808-1811.

Patil, B. T., Rode, V. R., Bhalekar, M. N. and Shinde, K. G. (2017). Studies on genetic variability, heritability and genetic advance in okra [Abelmoschus esculentus (L.) Moench]. Int. J. Agri. Env. Res., 3(2): 197-201.

Patil, B. T., Rode, V. R., Bhalekar, M. N. and Shinde, K. G. (2017). Studies on genetic variability, heritability and genetic advance in okra [Abelmoschus esculentus (L.) Moench]. Int. J. Agri. Env. Res., 3(2): 197-201.

Phanikrishna, M., Hameedunnisa, B., Rao, A. M. and Kumar, N. S. (2015). Estimation of heritability and genetic advance in okra [Abelmoschus esculentus (L.) Moench.]. Pl. Archives, 15(1): 489-491.

Pooja, C., Chaukhande, P.B. and Dod, V.N. (2011). Genetic variability in okra [Abelmoschus esculentus (L.) Moench], Asian J. Hort., 6(1): 241246.

Prakash, K., Pitchaimuthu, M., Venugopalan, R., Hongal, S. and Jainag, K. (2011a). Variability, heritability and genetic advances studies in okra [Abelmoschus esculentus (L.) Moench]. The Asian J. Horti., 6(1): 124-127.

Priyanka, D. V., Reddy, M. T., Begum, H., Sunil, N. and Jayaprada, M. (2018). Studies on genetic variability, heritability and genetic advance in genotypes of okra [Abelmoschus esculentus (L.) Moench]. Int. J. Curr.
Microbiol. App. Sci., 7(5): 401-411.

Ramanjinappa, V., Arunkumar, K. H., Hugar, A. and Shashibhaskar, M. S. (2011). Genetic variability in okra [Abelmoschus esculentus (L.) Moench]. Pl. Archives, 11(1): 435-437.

Rekha, H. H., Shantappa, T. and Shivanand, B. (2015). Genetic variability, heritability and genetic advance in okra biparental progenies. Int. J., 3(4): 1199-1203.

Sharma, P. K., Mishra, D. P. and Pandey, A. (2016). Genetic variability studies for yield and its contributing traits in okra [Abelmoschus esculentus (L.) Moench]. J. App. \& Natural Sci., 8(3): 1634-1637.

Sharma, R. K. and Prasad, K. (2015). Genetic divergence, correlation and path coefficient analysis in okra. Indian $J$. Agric. Res., 49(1): 77-82.

Shivaramegowda, K. D., Krishnan, A., Jayaramu, Y. K., Kumar, V. and Koh, H. J. (2016). Genotypic variation among okra [Abelmoschus esculentus (L.) Moench] germplasms in South India. Pl. Bree. and Biotech., 4(2): 234-241.

Singh, N., Singh, D. K., Sati, U. C., Rawat, M. and Pandey, P. (2017). Genetic analysis studies in okra [Abelmoschus esculentus (L.) Moench]. Int. J. Pure App. Biosci., 5(4): 361-367.

Sundaram, V. and Rajkumar, P. (2015). Genetic analysis in okra [Abelmoschus esculentus (L.) Moench]. Asian J. Horti., 10(1): 173-176.

Ullangula, S. (2017). Studies on variability, heritability and genetic advance in okra [Abelmoschus esculentus (L.) Moench]. Int. J. Curr. Microbiol. App. Sci., 6(10): 1834-1838.

Vishwas (2019). Genetic diversity, character association and path coefficient analysis in coriander (Coriandrum sativum L.). M. Sc. (GPB) thesis, 
Navsari Agricultural University, Yadav, R. K., Syamal, M. M., Pandiyaraj, P., Navsari. Gujarat.

Vrunda, R., Patel, A. I., Rathod, S., Sumita, Z., Vashi. J. M. and Chaudhari, B. N. (2018). Genetic variability, heritability and genetic advance studies in okra [Abelmoschus esculentus (L.) Moench]. Int. J. Chem. Stu., 6(3): 3319-3321. Nagarajan, K., Nimbolakar, P. K. and Kumar, M. (2016). Evaluation of genetic variation, heritability and genetic advance for various traits in okra [Abelmoschus esculentus (L.) Moench] under north gangetic plains of Uttar Pradesh. Int. J. Agri., Env. and Biotech., 9(2): 175-180.

\section{How to cite this article:}

Dhaval Rathava, A. I. Patel, J. M. Vashi and Chaudhari, B. N. 2019. Assessment of Genetic Diversity in Elite Genotypes of Okra [Abelmoschus esculentus (L.) Moench]. Int.J.Curr.Microbiol.App.Sci. 8(10): 2474-2483. doi: https://doi.org/10.20546/ijcmas.2019.810.287 